\title{
A functional Campylobacter jejuni maf4 gene results in novel glycoforms on flagellin and altered autoagglutination behaviour
}

Correspondence

Jos P. M. van Putten

j.vanputten@uu.nl

Received 23 April 2008

Revised 8 July 2008

Accepted 16 July 2008

\author{
Lieke B. van Alphen, ${ }^{1} \dagger$ Manfred Wuhrer, ${ }^{2}$ Nancy M. C. Bleumink-Pluym, ${ }^{1}$ \\ Paul J. Hensbergen, ${ }^{2}$ André M. Deelder ${ }^{2}$ and Jos P. M. van Putten ${ }^{1}$ \\ ${ }^{1}$ Department of Infectious Diseases and Immunology, Utrecht University, Yalelaan 1, $3584 \mathrm{CL}$ \\ Utrecht, The Netherlands \\ ${ }^{2}$ Biomolecular Mass Spectrometry Unit, Department of Parasitology, Leiden University Medical \\ Center, Albinusdreef 2, 2300 RC Leiden, The Netherlands
}

\begin{abstract}
Flagellin of Campylobacter jejuni is extensively modified with (derivatives of) pseudaminic acid. The flagellar glycosylation locus contains several genes with homopolymeric G-tracts prone to slipped-strand mispairing, some of which belong to the maf gene family. We investigated the function of the putative phase-variable maf4 gene of $C$. jejuni strain 108. A constructed maf4 mutant displayed unaltered flagella assembly and bacterial motility. 2D-PAGE analysis revealed that the flagellin of strain 108 migrated at a more acidic pl than the protein of the Maf4 mutant. MS-MS in combination with high-resolution matrix-assisted laser desorption/ionization Fourier transform ion cyclotron MS (MALDI-FT-ICR-MS) on flagellin-derived glycopeptides showed that the flagellins of the mutant lacked two previously unidentified modifications of pseudaminic acid. These glycoforms carried additional $\mathrm{CO}_{2}$ and $\mathrm{C}_{2} \mathrm{H}_{2} \mathrm{O}_{2}$ groups, consistent with the more acidic $\mathrm{pl}$ of the wild-type flagellin. Phenotypically, the maf4 mutant displayed strongly delayed bacterial autoagglutination. Collectively, our results suggest that the presence of a functional Maf4 expands the flagellin glycan repertoire with novel glycoforms of pseudaminic acid and, in the event of phase variation, alters the population behaviour of C. jejuni.
\end{abstract}

\section{INTRODUCTION}

Flagella are important bacterial organelles that enable swimming of microbes through watery environments and may contribute to bacterial pathogenesis by facilitating tissue colonization (Caldwell et al., 1985). The flagellar apparatus is composed of three basic elements: the basal body that is embedded in the membrane and contains the flagellar rotor, a short filamentous hook structure that protrudes into the extracellular environment, and a long polymeric filament that is mainly built up of thousands of flagellin subunits. Each flagellin molecule typically consists of two $\alpha$-helical structures formed by the $\mathrm{N}$ - and $\mathrm{C}$ -

† Present address: Department of Biological Sciences, M469, Biological Sciences building, University of Alberta, Edmonton, AB T6G 2E9, Canada.

Abbreviations: MALDI-FT-ICR-MS, matrix-assisted laser desorption/ ionization Fourier transform ion cyclotron MS; Pse5Ac7Ac, 5,7 diacetamido-3,5,7,9 tetradeoxy-L-glycero-L-manno-nonulosonic acid (pseudaminic acid); Pse5Am7Ac, pseudaminic acid with acetamido group substituted with acetamidino groups.

The GenBank/EMBL/DDBJ accession numbers for the maf4 gene and the glycosylation locus of the neuB3 to maf2 sequences of Campylobacter jejuni strain 108WT are EU448320 and EU448321, respectively. terminal regions of the protein that are buried in the core of the filament, and a central hypervariable surface-exposed domain (Samatey et al., 2001). In some bacterial species the flagellin protein undergoes post-translational modifications (for a review, see Logan, 2006). The function of these modifications is unknown, but they contribute to the serospecificity of the flagellin (Alm et al., 1991).

Post-translational modification of flagellin was first demonstrated in Campylobacter species (Logan et al., 1989). Further characterization of flagellin using periodate treatment, specific lectins (Doig et al., 1996), and, at a later stage, state-of-the-art chemical analysis (Logan et al., 2002; McNally et al., 2006, 2007; Thibault et al., 2001) indicates the presence of $O$-linked carbohydrate residues. To date, the flagellin of Campylobacter jejuni strain 81-176 is known to be decorated predominantly with 5,7 diacetamido-3,5,7,9 tetradeoxy-L-glycero-L-manno-nonulosonic acid (pseudaminic acid, Pse5Ac7Ac), which is attached to up to 19 different Ser/Thr residues in the flagellin. Substitution of the acetamido group of pseudaminic acid with acetamidino groups (Pse5Am7Ac), hydroxyproprionyl groups (Pse5Pr7Pr), N-acetylglucosamine (Pse5Am7AcOGlnAc) or acetyl groups (Pse5Am7Ac8OAc) (Schirm et al., 2005) causes further heterogeneity in the carbohydrate moieties 
(Thibault et al., 2001). This heterogeneity is evident from the migration of flagellin as separate glycoforms during IEF (Logan et al., 2002). Recently, other glycosyl groups, namely legionaminic acid and derivatives thereof, have been detected on the flagella of Campylobacter coli VC167 (McNally et al., 2007). Thus, Campylobacter appears to have evolved a considerable repertoire of carbohydrate structures to decorate its flagella.

The genes known to contribute to the glyco-modification of Campylobacter flagellin are clustered in a single locus, the flagellar glycosylation locus (Guerry et al., 2006). The locus varies in size in different Campylobacter strains and contains genes involved in the synthesis of Pse5Ac7Ac, as well as a family of up to seven very homologous genes, termed the Cj1318 or maf gene family. The function of these genes is under active investigation. maf2 ( $p s e D)$, but not maf3, maf6 or maf7, in strain 81-176 appears to be involved in flagellin glycosylation (Guerry et al., 2006), while maf5 (pseE) in strain 11168 is required for flagella assembly (Karlyshev et al., 2002). Analysis of the flagellin in a pseD mutant has demonstrated that it contains Pse5Ac7Ac but lacks Pse5Am7Ac on flagellin (Guerry et al., 2006). However, intracellular CMP-Pse5Am7Ac was detected, suggesting a role in glycosyl transfer to flagellin and not in monosaccharide biosynthesis. This is in contrast to a pseA mutant, which lacks intracellular CMPPse5Am7Ac, suggesting a defect in biosynthesis (McNally et al., 2006).

Some of the maf genes including the (identical) maf1 and maf4 genes of strain 11168 contain a homopolymeric Gtract that is prone to slipped-strand mispairing, which may result in a shift of the ORF (Karlyshev et al., 2002). The exact functions of these maf genes are unknown, as in most strains they appear to be in the 'off' state or are not present at all. In the present study we investigated the function of the potentially phase-variable maf4 gene in $C$. jejuni strain 108. In this strain the gene is in the 'on' state, and thus encodes a full-length Maf4 protein. Targeted gene inactivation combined with phenotypic analysis with respect to flagellin glycosylation, flagella-mediated bacterial agglutination, and the ability to cause infection of host cells, revealed that Maf4 is not required for flagellar assembly, but does alter flagellin glycosylation and bacterial agglutination behaviour. Thus, phase variation of maf4 may serve to change the functional properties of Campylobacter flagellin.

\section{METHODS}

Bacteria and cell culture. Wild-type C. jejuni 108 (129108, 108WT; Endtz et al., 1993) and its derivatives were routinely grown on saponin agar plates with $4 \%$ lysed horse blood or in $5 \mathrm{ml}$ heart infusion (HI) broth under microaerophilic conditions at $37^{\circ} \mathrm{C}$, unless indicated otherwise. Chang (CCL-20.2, ATCC) and INT-407 (CCL-6, ATCC) epithelial cells were routinely maintained in RPMI (Gibco) supplemented with $5 \%$ fetal bovine serum (FBS) or Dulbecco's minimal essential medium (DMEM; Gibco) supplemented with $10 \%$ FBS in a humidified $37{ }^{\circ} \mathrm{C}$ atmosphere of 5 or $10 \%$ $\mathrm{CO}_{2}$, respectively.

Analysis of the maf glycosylation locus. The sequence of the glycosylation locus of 108WT from neuB3 to maf2 (GenBank accession no. EU448321) was determined (Baseclear) after amplification by PCR using primer sets Mafl Fwd + NeuC Rev and NeuC Fwd + Maf2 Rev (Table 1), and subsequent cloning of the PCR fragments into pGEM-T easy. The sequence of maf4 of strain 108WT (GenBank accession no. EU448320) was determined after amplification of the corresponding gene by PCR with primer set Maf4 Fwd + Maf4 Rev using Taq polymerase with proofreading (Invitrogen) and cloning of the resulting PCR product into pGEMT easy. The primer set Maf4 Fwd + FlaB Rev was used to verify that the maf3-flaB region was of the expected size.

Construction of C. jejuni 108 maf4 mutants. Genetic inactivation of maf4 was accomplished by amplifying the corresponding gene and the flanking region by PCR with the primers Maf4 Fwd and Maf4 Rev. PCR fragments were cloned into the vector pGEM-T easy and transformed into Escherichia coli DH5 $\alpha$. Purified plasmid was used as a template in an outward-directed PCR with primers $\triangle$ Maf4 Fwd and $\Delta$ Maf4 Rev, which yielded products that lacked $\sim 260 \mathrm{bp}$ of coding sequence and carried $\mathrm{Bam} \mathrm{HI}$ restriction sites at the ends. These sites served to introduce a chloramphenicol-resistance cassette derived from pAV35 (van Vliet et al., 1998). The resulting vector, pGmaf4::cat, with the chloramphenicol cassette in the same orientation as maf4, was introduced into C. jejuni 108 WT and $108 \mathrm{P} 4$ via electroporation, and chloramphenicol $\left(20 \mu \mathrm{g} \mathrm{ml}{ }^{-1}\right)$ resistant transformants were selected after $48 \mathrm{~h}$ growth on saponin agar plates. Targeted gene disruption was verified by PCR.

Table 1. Primers used in this study

\begin{tabular}{|ll|}
\hline Primer & \multicolumn{1}{c|}{ sequence } \\
\hline Maf1 Fwd & 5'-GCAAGAAGCTTATATGCAAGTAAGG-3' \\
NeuC Rev & 5'-CCATTCAGCCCTTGTTGCACTGAC-3' \\
NeuC Fwd & 5'-GTCAGTGCAACAAGGGCTGAATGG-3' \\
Maf2 Rev & 5'-GGTGCTGTTGTAGGTGGTGAT-3' \\
Maf4 Fwd & 5'-GCTATTTATTTTCATAACGAATGCG-3' \\
Maf4 Rev & 5'-TCCCCGCGGTCACCTTCTCACCCTTTCCA-3' \\
FlaB Rev & 5'-TGTTAAAGCAGCTGAATCAACCA-3' \\
$\Delta$ Maf4 Fwd & 5'-CGGGATCCGAATATTACTTAAAGCCTCAAT-3' \\
$\Delta$ Maf4 Rev & 5'-CGGGATCC AATTCCATTTCCAAAACCATA-3' \\
\hline
\end{tabular}


Motility assay. To assess bacterial migration in semi-solid agar,

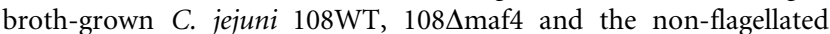
mutant $108 \Delta$ rpoN (Wösten, 1997) were stabbed into semi-solid medium (thioglycollate medium containing $0.4 \%$ agar). Swarming was assessed after incubation under microaerobic conditions at $37{ }^{\circ} \mathrm{C}$ for $24 \mathrm{~h}$.

Infection and gentamicin protection assay. Infection experiments were carried out as described previously (van Alphen et al., 2008) with some modifications. Briefly, for microscopic analysis, epithelial cells ( $75 \%$ confluence) were rinsed twice with serum-free medium and placed in $1 \mathrm{ml}$ of this medium in a microaerobic incubator at $30 \mathrm{~min}$ prior to infection. Bacteria grown in $\mathrm{HI}$ broth for $16 \mathrm{~h}\left(\mathrm{OD}_{550} 1.2\right)$ were collected by centrifugation $\left(3000 \mathrm{~g}, 10 \mathrm{~min}, 20{ }^{\circ} \mathrm{C}\right)$, resuspended in Dulbecco's PBS (DPBS), and added to the cells at an m.o.i. of 200. At $2 \mathrm{~h}$ of incubation (microaerophilic conditions, $37^{\circ} \mathrm{C}$ ), the cells were rinsed three times with $1 \mathrm{ml}$ DPBS and fixed $\left(>1 \mathrm{~h}, 20^{\circ} \mathrm{C}\right)$ in $1.5 \%$ formaldehyde in DPBS for microscopic analysis (van Putten et al., 1994). Bacterial subvasion was scored by multiplanar microscopy with counting of the number of bacteria per cell for 10 randomly selected microscopic fields. Bacterial viability during infection was assessed using the gentamicin protection assay. In this assay, $2 \mathrm{~h}$ infected cells were rinsed three times with $1 \mathrm{ml}$ DPBS, incubated (for $3 \mathrm{~h}$ ) in $0.5 \mathrm{ml}$ medium containing $250 \mu \mathrm{g}$ gentamicin $\mathrm{ml}^{-1}$, rinsed three times with $1 \mathrm{ml}$ DPBS, lysed with $250 \mu \mathrm{l} 0.1 \%$ Triton X-100 in DPBS ( $15 \mathrm{~min}, 20^{\circ} \mathrm{C}$ ), and plated at various dilutions to quantify the number of viable bacteria. No viable bacteria were recovered from the culture supernatant after gentamicin treatment. Experiments were performed in duplicate and the mean \pm SEM of three separate experiments are presented.

Autoagglutination (AAG) assays. For AAG assays, bacteria grown in $\mathrm{HI}$ broth $\left(16 \mathrm{~h}, 37^{\circ} \mathrm{C}\right)$ were collected by centrifugation $(3000 \mathrm{~g}$, $5 \mathrm{~min}$ ) and resuspended in DPBS to a final $\mathrm{OD}_{550}$ of 0.5 . Bacterial suspensions were transferred to glass tubes and kept at room temperature. At $45 \mathrm{~min}$ intervals, photographs were taken and $0.5 \mathrm{ml}$ samples of the top layer of suspension were collected for measurement of $\mathrm{OD}_{550}$.

Isolation of bacterial outer membranes. Bacteria grown on saponin agar plates $\left(16 \mathrm{~h}, 42{ }^{\circ} \mathrm{C}\right)$ or in $\mathrm{HI}$ broth $\left(16 \mathrm{~h}, 37^{\circ} \mathrm{C}\right)$ were collected and resuspended in $2 \mathrm{ml} 50 \mathrm{mM}$ Tris- $\mathrm{HCl}, \mathrm{pH}$ 7.5. After ultrasonic disruption (60 s on ice), crude fragments were removed by centrifugation $\left(12000 \mathrm{~g}, 30 \mathrm{~min}, 4^{\circ} \mathrm{C}\right.$ ) and bacterial membranes were collected $\left(50000 \mathrm{~g}, 1 \mathrm{~h}, 4{ }^{\circ} \mathrm{C}\right)$. Outer membranes were obtained by dissolving the inner membranes with $1 \%$ Sarkosyl in Tris- $\mathrm{HCl}$ buffer $\left(10 \mathrm{~min}, 20^{\circ} \mathrm{C}\right)$, followed by centrifugation $\left(50000 \mathrm{~g}, 2 \mathrm{~h}, 4{ }^{\circ} \mathrm{C}\right)$. The outer-membrane fraction was resuspended in Tris- $\mathrm{HCl}$ buffer and stored at $-20{ }^{\circ} \mathrm{C}$.

2D gel electrophoresis. For 2D electrophoresis, $50 \mu \mathrm{g}$ protein from bacterial outer membranes was mixed with rehydration solution containing $7 \mathrm{M}$ urea, $2 \mathrm{M}$ thiourea, $4 \%$ (w/v) CHAPS, $0.5 \%$ IPG buffer, $\mathrm{pH} 4-7$ (GE Healthcare) and $0.3 \%(\mathrm{w} / \mathrm{v})$ DTT to a final volume of $250 \mu$ l. Proteins were resolved in the first dimension by IEF

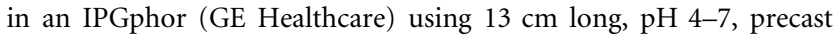
immobilized nonlinear $\mathrm{pH}$ gradient strips (GE Healthcare). The IEF parameters were as follows: rehydration was carried out for $11 \mathrm{~h}$ at $30 \mathrm{~V}$, followed by $500 \mathrm{~V}$ for $1 \mathrm{~h}, 1000 \mathrm{~V}$ for $1 \mathrm{~h}, 8000 \mathrm{~V}$ for $5 \mathrm{~h}$, and $500 \mathrm{~V}$ for $30 \mathrm{~min}$. Then, the strips were equilibrated (for $15 \mathrm{~min}$ ) in $5 \mathrm{ml}$ buffer I ( $50 \mathrm{mM}$ Tris- $\mathrm{HCl}, \mathrm{pH} 8.8,6 \mathrm{M}$ urea, $2 \%$ SDS, $30 \%$, w/ $\mathrm{v}$, glycerol and $\left.10 \mathrm{mg} \mathrm{DTT} \mathrm{ml}^{-1}\right)$, and subsequently for $15 \mathrm{~min}$ in $5 \mathrm{ml}$ buffer II (50 mM Tris- $\mathrm{HCl}, \mathrm{pH} 8.8,6 \mathrm{M}$ urea, $2 \%$ SDS, $30 \%$, $\mathrm{w} / \mathrm{v}$, glycerol and $25 \mathrm{mg}$ iodoacetamide $\mathrm{ml}^{-1}$ ). Strips were placed on $12.5 \%$ polyacrylamide gels and run for $30 \mathrm{~min}$ at $15 \mathrm{~mA}$ and then at $30 \mathrm{~mA}$ until the front reached the bottom of the gel, using an LBK
Hoefer Scientific cell apparatus. Proteins were visualized by staining with silver (Shevchenko et al., 1996).

Western blotting of flagellar proteins. For Western blotting, the procedure described above for 2D gel electrophoresis was used, with modifications to suit a minigel system. Separated proteins were transferred to Hybond-C Extra nitrocellulose using a Bio-Rad miniblot system (GE Healthcare). Filters were incubated with antiFlaAB antiserum and, subsequently, with horseradish-peroxidaseconjugated goat anti-rabbit IgG (Santa Cruz Biotechnology). Immune-reactive bands were visualized with Super Signal West Pico chemiluminescent substrate (Pierce).

MS. Coomassie-stained flagellin protein bands $(64 \mathrm{kDa})$ were excised from gels after separation of outer-membrane proteins on $8 \%$ SDSPAGE gels. Subsequently, flagellin proteins were reduced, alkylated and in-gel digested using trypsin (modified, sequencing grade, Promega) as described elsewhere (Steen et al., 2002). After digestion, peptides were collected using two rounds of extraction with $0.1 \%$ trifluoroacetic acid and stored at $-20{ }^{\circ} \mathrm{C}$ until further use. For the analysis of tryptic (glyco)peptides, samples were injected onto a Nano LC System (Ultimate, Dionex) equipped with a peptide trap column [Pepmap 100, $300 \mu \mathrm{m}$ inner diameter (i.d.) $\times 10 \mathrm{~mm}$ ] and an analytical column (Pepmap 100, $75 \mu \mathrm{m}$ i.d $\times 150 \mathrm{~mm}$, Dionex). The mobile phases consisted of (A) $0.04 \%$ formic acid $/ 0.4 \%$ acetonitrile and (B) $0.04 \%$ formic acid $/ 90 \%$ acetonitrile. A 45 min linear gradient from 0 to $60 \% \mathrm{~B}$ was applied at a flow rate of $0.2 \mu \mathrm{l} \mathrm{min}{ }^{-1}$. The outlet of the LC system was coupled to an HCTultra ion-trap mass spectrometer (Bruker Daltonics) using a nano-electrospray ionization source. The spray voltage was set at $1.2 \mathrm{kV}$ and the temperature of the heated capillary was set to $165{ }^{\circ} \mathrm{C}$. Eluting peptides were analysed in the data-dependent MS/MS mode over a $400-1600 \mathrm{~m} / \mathrm{z}$ range. The five most abundant fragments in each MS spectrum were selected for MS/MS analysis by collision-induced dissociation. For an accurate mass analysis, the tryptic digest of bacterial flagellins of 108WT was separated by reverse-phase HPLC, and $3 \mathrm{~min}$ fractions were collected. Fractions were dried in a vacuum centrifuge, resuspended in $50 \mu \mathrm{l}$ water, and $1 \mu \mathrm{l}$ was spotted on a stainless steel target plate together with $1 \mu \mathrm{l} 2$,5-dihydroxybenzoic acid (DHB; $20 \mathrm{mg} \mathrm{ml}^{-1}$ in $30 \%$ acetonitrile), allowed to dry at ambient temperature and analysed by matrix-assisted laser desorption/ionization Fourier transform ion cyclotron MS (MALDI-FTICR-MS; ApexUltra equipped with a combisource, Bruker Daltonics). An internal calibration was performed for the spectrum obtained from fraction 5 using the theoretical masses of various nonglycosylated peptides detected in this fraction. Obtained accurate masses for the various glycoforms of peptide $\mathrm{T}_{465}-\mathrm{K}_{481}$ of FlaA/FlaB were used for the calculation of the masses of the $[\mathrm{M}+\mathrm{H}]^{+}$species of the glycan moieties. Suggestions for elemental compositions of the glycan moieties were obtained from these calculated masses using an online tool (http://www.ch.cam.ac.uk/magnus/EadFormW.html).

\section{RESULTS}

\section{Identification of phase-variable maf genes}

In silico analysis of seven sequenced $C$. jejuni flagellar glycosylation loci revealed the presence of a variable number of maf genes, with a minimum of four per strain (Fig. 1b). In four out of seven sequenced strains, one or two of the maf genes (named mafl and maf4) contain a homopolymeric G-tract prone to slipped strand mispairing. When all putative phase-variable maf genes were altered in their poly-G region to translate into the largest 
(a)

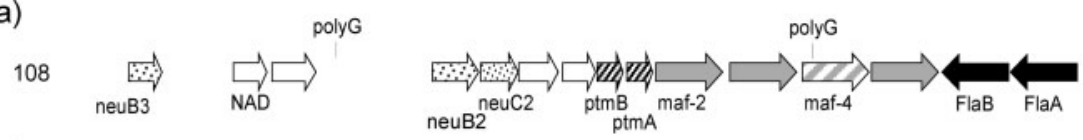

(b)
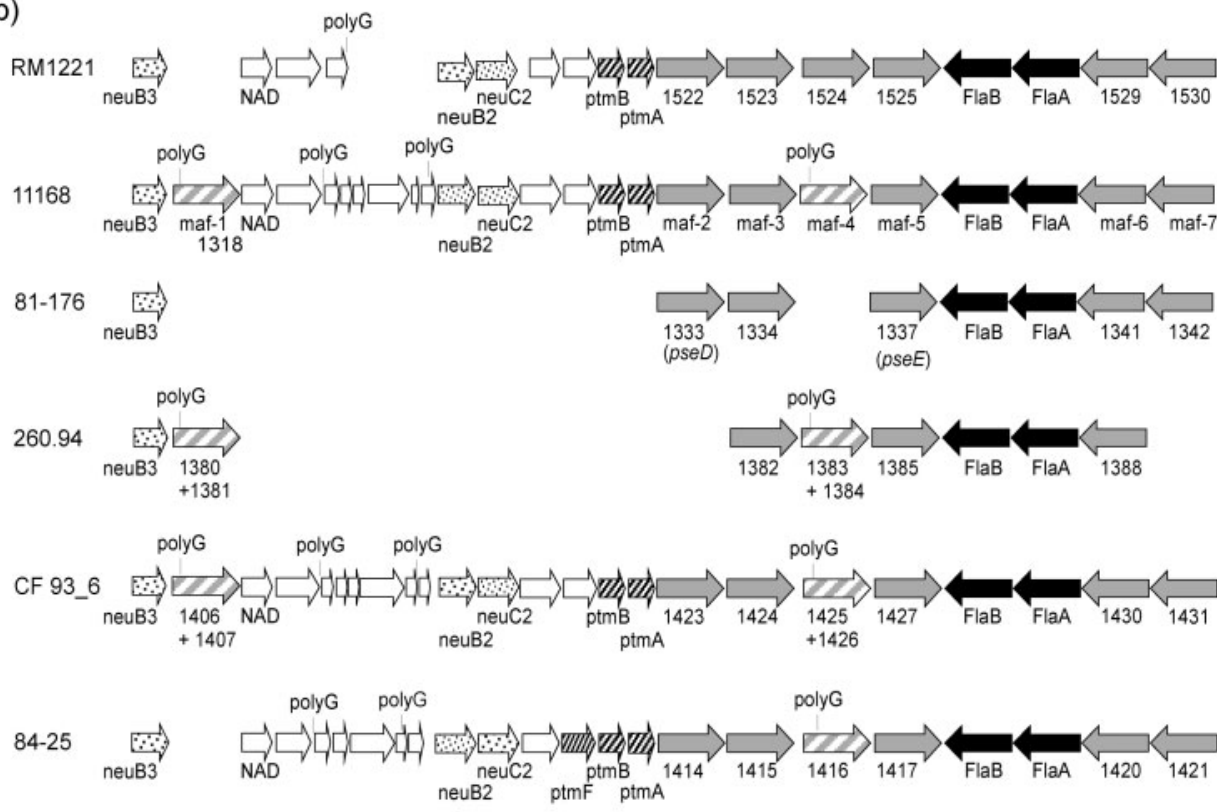

HB93-13 neuB3 $2 \mathrm{~kb}$
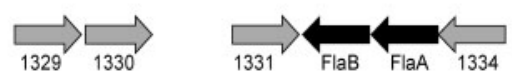

Fig. 1. Schematic representation of the organization of the maf (1318) gene family within the flagellar glycosylation locus of (a) C. jejuni 108 and (b) sequenced C. jejuni strains. The numbers underneath the genes refer to the gene numbers in the corresponding strain. The bar represents $2.0 \mathrm{~kb}$. polyG, location of a stretch of $\mathrm{G}$ residues. Variable shading of the arrows indicates differences in the predicted function and similarity of the genes: grey, maf family or related genes; hatched grey lines, phase-variable maf family genes; solid black, flagellin genes; hatched black lines, genes involved in flagellin modification; dots, putative $\mathrm{N}$-acetylneuraminic acid synthetases; solid white, other genes.

possible ORF, their alignment showed in all cases high similarity (63-99\%) at the amino acid level to Maf1 of strain 11168 . When two potentially phase-variable genes were present in one strain they had virtually identical sequences (with the exception of strain CF93_6), suggesting that they evolved by gene duplication. Furthermore, the location of these maf genes within the glycosylation locus seemed conserved in all strains: either directly downstream of neuB3, which encodes the enzyme sialic acid synthase, or $\sim 2000$ bp downstream of the flagellin locus (Fig. 1b). Two exceptions in the characteristics of mafl/4-like genes were the presence of a phase-variable gene (Cj1383/1384) in strain 260.94 that was most similar to maf3 rather than mafl/4, and the presence of a maf4 gene with a seemingly deleted poly-G tract region in strain RM1221.

On the basis of phylogenetic and molecular evolutionary analyses conducted using MEGA version 3.1 (Kumar et al., 2004), the maf genes fall into different clusters (Fig. 2) that sometimes do not follow the current gene nomenclature. For example, the maf2 genes from strain 81-176 (Cj1333),
HB9313 (CJJ1329) and 260.94 (CJJ1382) appear to belong in one group with the maf 3 gene family of the other four strains, while the maf3 genes of strains 81-176 (Cj1334), HB9313 (CJJ1330) and 260.94 (CJJ1383+1384) better fit the maf2 gene cluster (Fig. 2). Furthermore, on the basis of sequence similarity, the maf genes located upstream of flaA form a distinct category and appear to belong to the maf6 and maf7 gene cluster (Fig. 2). However, for the potentially phase-variable mafl/4 genes the current nomenclature was consistent with the MEGA analysis.

\section{Identification of maf1/4-like gene(s) in strain 108}

PCR and sequence analysis of the glycosylation locus of $C$. jejuni strain 108WT downstream of neuB3 demonstrated a similar organization to that in strain RM1221 (Fig. 1a). No maf gene was detected adjacent to neuB3, in contrast to the situation in several other strains including strain 11168 (Fig. 1b). A putative maf4 gene was located at the same position in the glycosylation locus as in strains RM1221 and 11168. Sequencing of this gene indicated the presence of a poly-G 


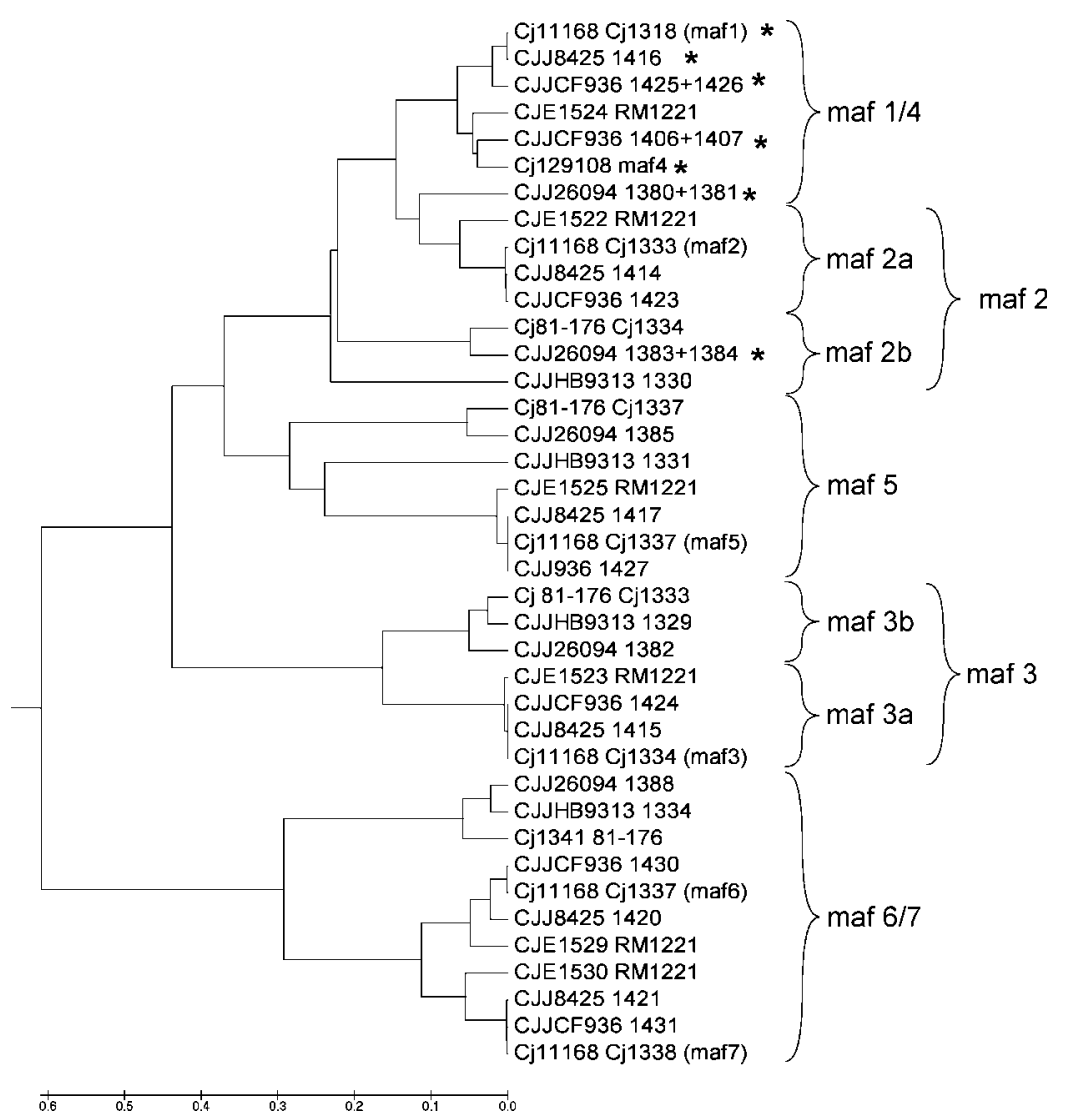

Fig. 2. Neighbour-joining tree of aligned maf genes of all sequenced strains. The phasevariable maf genes are indicated by asterisks. These maf genes form a separate cluster, with one exception (the maf3 CJJ1383+1384 gene of strain 260.94). For strains in which maf1 and maf4 are gene duplications, only maf1 is depicted. tract in the $5^{\prime}$-terminal region of the gene. The gene contained an intact ORF that was highly similar at the amino acid level to the in-frame phase-variable mafl/4 sequences of strain 11168 , with the exception of two distinct regions of $12-50$ amino acids in length (Fig. 3). These regions were most similar to the corresponding region of the potentially phasevariable maf1 of strain 260.94 and the non-phase-variable maf4 of strain RM1221 (Fig. 3). This architecture suggests that the Maf proteins may consist of variable peptide modules embedded in a relatively conserved protein backbone.

\section{Role of maf4 in flagella assembly and bacterial motility}

As strain 108 contained only a single maf1/4 gene encoding a full-length protein (in contrast to strain 11168), we used this strain to investigate the function of the maf4 gene in $C$. jejuni biology. Gene inactivation of maf4 in strain 108 was accomplished by allelic replacement with a maf4 gene copy in which 260 bp was deleted and replaced by a chloramphenicol-resistance cassette. PCR confirmed the correct insertion of the disrupted gene copy (not shown). Phenotypic analysis demonstrated that the 108maf4: : cat

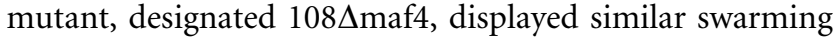
behaviour in semi-solid thioglycollate agar to the parent strain (Fig. 4a). These data indicate that Maf4 is not required either for flagella assembly or for bacterial motility, in contrast to Maf5 (Karlyshev et al., 2002).

\section{Maf4 is involved in the glycosylation of C. jejuni flagellin}

The finding that inactivation of maf4 still allowed flagella formation enabled us to investigate the glycosylation status of the flagellin in the mutant strain. For this purpose,

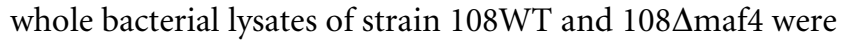
analysed by 2D-PAGE. This demonstrated that flagellin of strain 108WT was heterogeneous with respect to its $\mathrm{pI}$, suggesting variable post-translational modifications. For the mutant strain a similar migration pattern was observed, except that the most dominant protein forms had shifted towards a more neutral pI (from 4.5-5.0 to 5.0-5.5) (Fig. $4 \mathrm{~b})$. This shift was more pronounced when bacteria were grown at $37{ }^{\circ} \mathrm{C}$ than at $42{ }^{\circ} \mathrm{C}$ (data not shown). No shift in apparent molecular mass of the flagellins was observed in the wild-type compared with the maf4 mutant (Fig. 4b). Western blotting with a flagellin-specific mAb demonstrated that the shifted spots correspond to flagellin (data not shown). Furthermore, MS-MS of tryptic digests confirmed the spots to be FlaA and FlaB.

\section{Inactivation of maf4 alters flagellin glycoforms}

In order to elucidate molecular differences between the

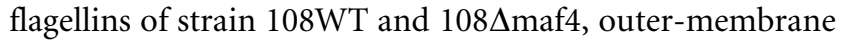
fractions containing high amounts of flagellin were prepared and subjected to SDS-PAGE. Flagellin bands 


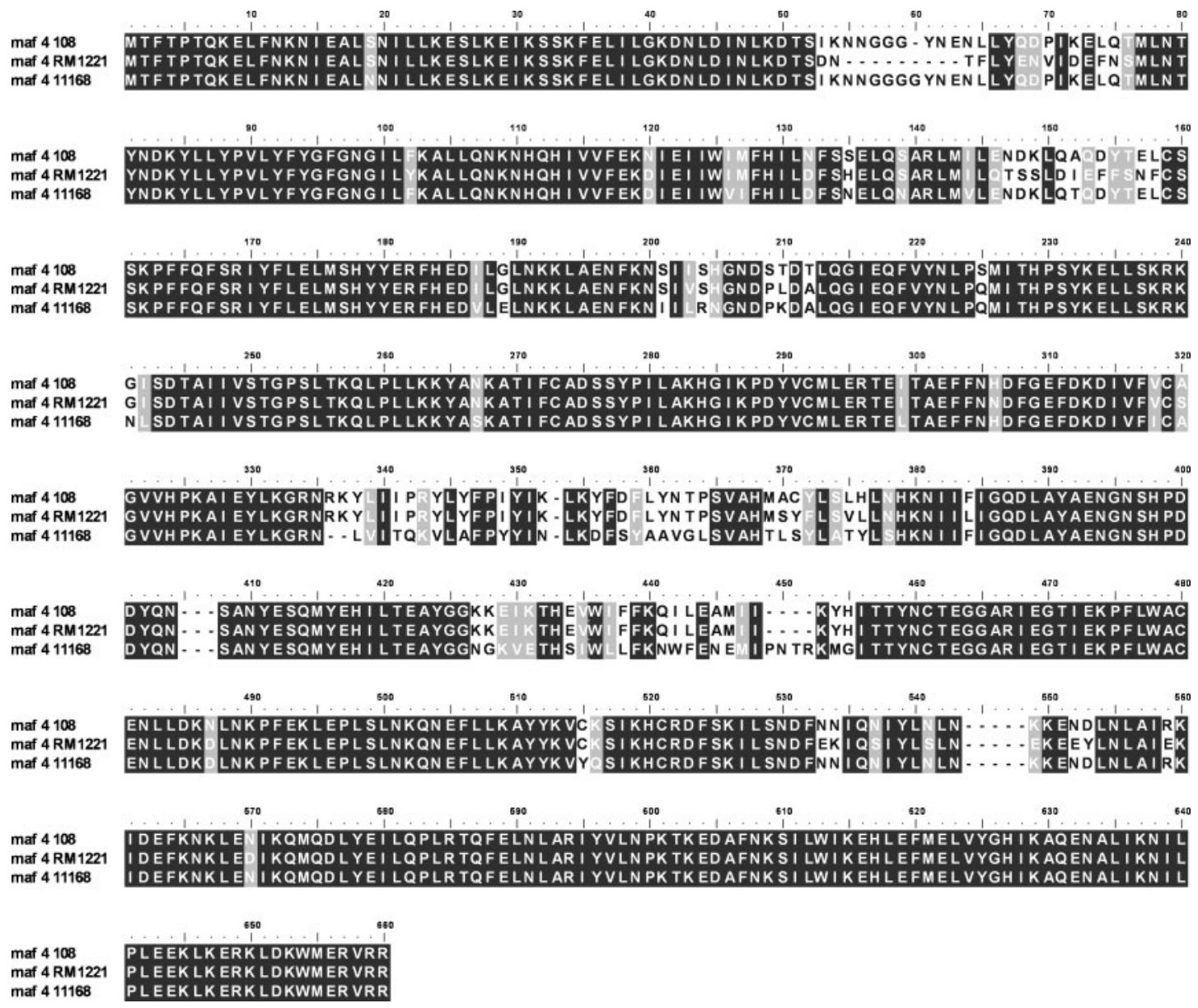

Fig. 3. Alignment of the Maf4 protein of strain 108 with the corresponding genes of strains RM1221 and 11168 . Note that the highly conserved regions are interspersed by two highly variable regions, which show high similarity to maf4 (CJE1524) of RM1221, but are different from maf4 (Cj1318 or Cj1335+1336) of 11168. Identical amino acids are shaded black, similar amino acids grey.

were excised, in-gel-digested with trypsin, and subsequently analysed by nano reverse-phase HPLC ion-trap MS-MS (Fig. 5). The samples showed very similar patterns of both non-glycosylated peptides and glycopeptides. The obvious differences in the chromatogram (e.g. an additional peak for the mutant sample at 16 min; Fig. 5a) were caused by differences in the extent of methionine oxidation, most likely introduced during sample workup, and could not explain the differences observed in isoelectric points observed in the 2D-PAGE gels.

Candidate glycopeptides were identified by their characteristic tandem mass spectra. Due to its pronounced lability the $O$-glycosidic linkage was predominantly cleaved on collisional activation, resulting in oxonium ions of the bacterial monosaccharides next to a prominent signal of the deglycosylated peptide moiety. A manual screening of the MS/MS dataset revealed many glycopeptides with one or two monosaccharides attached (Table 2). The prevailing monosaccharides were Pse5Ac7Ac and Pse5Am7Ac, which were indicated by oxonium ions of $\mathrm{m} / z 317$ and $\mathrm{m} / z 316$, respectively.

Screening of the LC-MS/MS dataset for possible differences between the flagellins of strains $108 \mathrm{WT}$ and $108 \Delta$ maf4 indicated differential glycosylation of the peptide $\mathrm{T}_{465} \mathrm{SVLGVK}_{471}$, which is shared between FlaA and FlaB. In strain $108 \mathrm{WT}$, this peptide stretch was in part occupied by Pse5Am7Ac and Pse5Ac7Ac, resulting in glycopeptide ions (peptide moiety $\mathrm{T}_{465}-\mathrm{K}_{481}$, one missed tryptic cleavage site) of $\mathrm{m} / z 678.7$ (at $17 \mathrm{~min}$ ) and $\mathrm{m} / z 679.1$ (at $19 \mathrm{~min}$ ), respectively. These glycoforms were also detected for $108 \Delta$ maf4, yet in different ratios and at higher abundances, as evidenced by the extracted ion chromatograms shown in Fig. 5(b). Moreover, in strain 108WT two additional glycoforms of the peptide were observed which were absent in 108 $\Delta$ maf4. The prevailing glycoform $(\mathrm{m} / z \quad 693$ $[\mathrm{M}+3 \mathrm{H}]^{3+}$, continuous line, and $\mathrm{m} / z 1039[\mathrm{M}+2 \mathrm{H}]^{2+}$, dashed line; Fig. 5b) contained a carbohydrate residue, which, to the best of our knowledge, has not been 

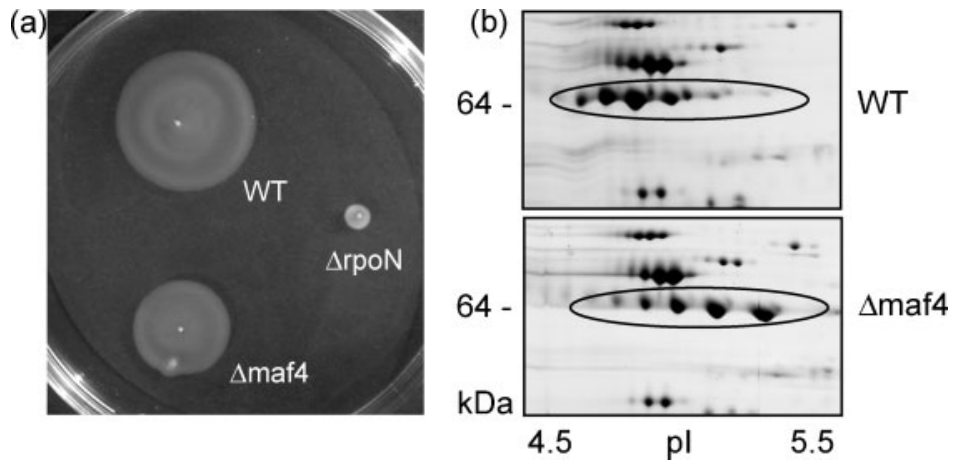

Fig. 4. (a) Swarming assay for strain $108 \mathrm{WT}$, the $108 \Delta$ maf4 mutant ( $\Delta$ maf4) and the nonflagellated mutant $108 \Delta \mathrm{rpoN}(\Delta \mathrm{rpoN})$. (b) 2D analysis of outer-membrane protein spots of both strains as visualized with silver. Encircled spots represent flagellin. Note the shift of the flagellar spots of $108 \Delta$ maf 4 to a less acidic pl. described before. MS-MS of this glycopeptide led to an oxonium ion, which, after elimination of water, resulted in a signal at $m / z 342$ (Fig. 5e). The deglycosylated peptide was observed at $m / z 860\left([\mathrm{M}+2 \mathrm{H}]^{2+}\right)$, which was also the dominant fragment observed for the glycoforms with Pse5Am7Ac (Fig. 5c) and Pse5Ac7Ac (Fig. 5d). The

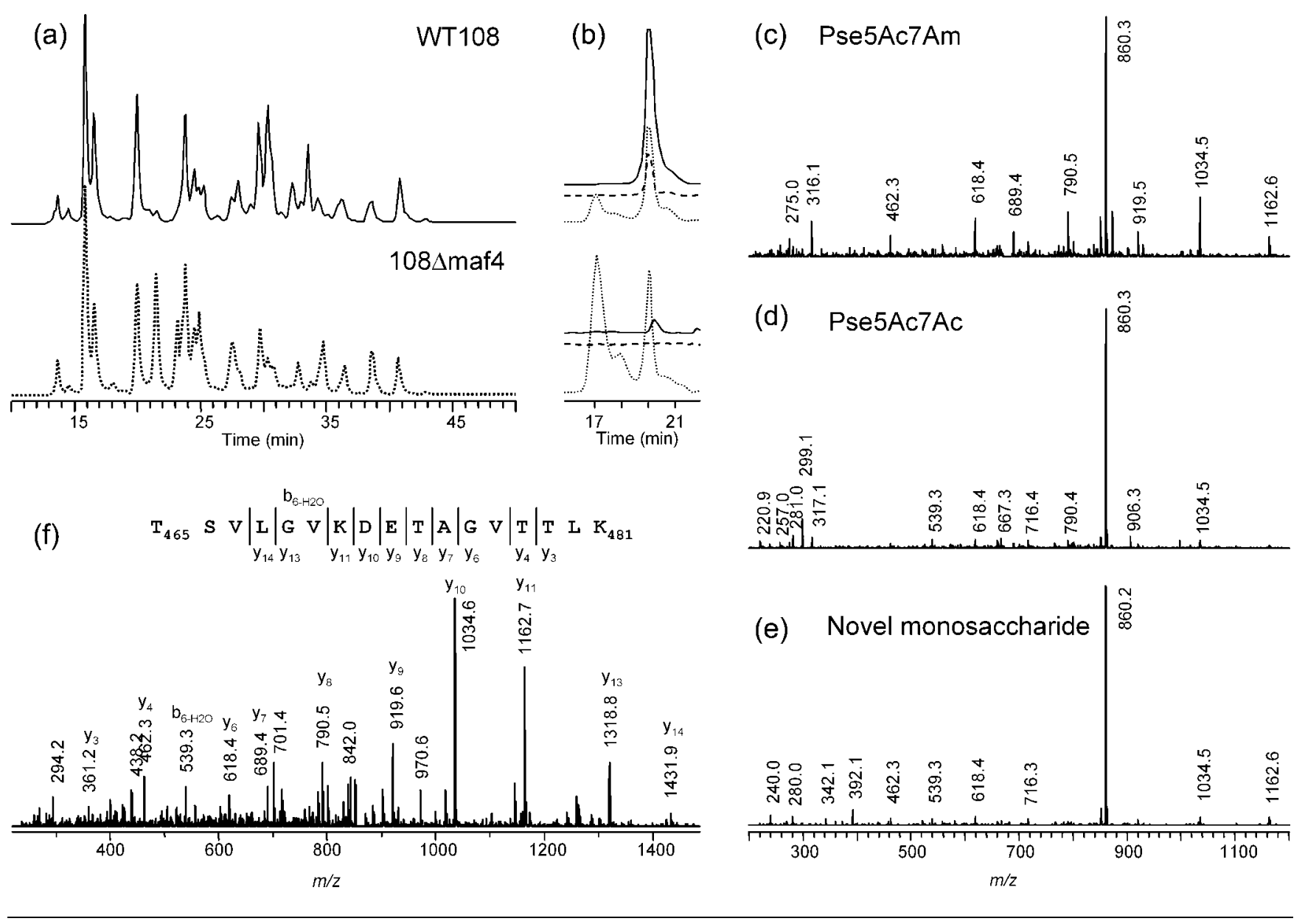

Fig. 5. Nano reverse-phase HPLC ion-trap MS-MS analysis of bacterial flagellins after tryptic digestion. Tryptic (glyco-) peptides from flagellins of strain 108WT and the 108 $\Delta$ maf4 mutant were analysed by nano reverse-phase HPLC ion-trap MSMS. (a) Base-peak chromatograms for wild type (upper panel) and mutant (lower panel). (b) Extracted-ion chromatograms of $\mathrm{m} /$ $z 693$ (continuous line), $\mathrm{m} / \mathrm{z} 1039$ (dashed line) and $\mathrm{m} / \mathrm{z}$ 678/679 (dotted line), representing three glycoforms of the glycopeptide $\mathrm{T}_{465}-\mathrm{K}_{481}$ of Flag A. (c-e) lon trap tandem mass spectra of triple-charged glycoforms of $\mathrm{T}_{465}-\mathrm{K}_{481}$ of $m / z 678.7$ (c), $m / z 679.1$ (d) and $m / z 693.4$ (e) observed for the wild-type sample. (f) $\mathrm{MS}^{3}$ spectrum obtained from the double-charged fragment at 860.2 from panel (e), confirming the identity of the $\mathrm{T}_{465}-\mathrm{K}_{481}$ peptide moiety. 
Table 2. Analysis of tryptic glycopeptides from flagellins by nano reverse-phase HPLC ion-trap MS-MS

\begin{tabular}{|c|c|c|c|c|c|}
\hline Glycopeptide signal $(\mathrm{m} / \mathrm{z})$ & Deduced $[\mathrm{M}+\mathrm{H}]^{+}$ & MS-MS glycan marker ions & Peptide moiety & Flagellin & Glycan B-ion \\
\hline $510.3[\mathrm{M}+2 \mathrm{H}]^{2+}$ & 1019.6 & $240.1,281.1,299.1,317.1$ & $703.1[\mathrm{M}+\mathrm{H}]^{+} \mathrm{T}_{465} \mathrm{SVLGVK}_{471}$ (confirmed with $\mathrm{MS}^{3}$ ) & $\mathrm{A}, \mathrm{B}$ & 317.1 \\
\hline $531.8[\mathrm{M}+2 \mathrm{H}]^{2+}$ & 1062.6 & $240.1,280.1,324.1,342.1,360.2$ & $703.1[\mathrm{M}+\mathrm{H}]^{+} \mathrm{T}_{465} \mathrm{SVLGVK}_{471}$ & A, B & 360.1 \\
\hline $\begin{array}{l}509.3[\mathrm{M}+4 \mathrm{H}]^{4+} ; 678.7 \\
{[\mathrm{M}+3 \mathrm{H}]^{3+} ; 1017.6[\mathrm{M}+2 \mathrm{H}]^{2+}}\end{array}$ & 2034.2 & $275.1,316.1$ & $860.0[\mathrm{M}+2 \mathrm{H}]^{2+} \mathrm{T}_{465}$ SVLGVKDETAGVTTLK $_{481}$ & A, B & 316.1 \\
\hline $\begin{array}{l}679.1[\mathrm{M}+3 \mathrm{H}]^{3+} ; 1018.1 \\
{[\mathrm{M}+2 \mathrm{H}]^{2+}}\end{array}$ & 2035.2 & $299.1,317.1$ & $860.1[\mathrm{M}+2 \mathrm{H}]^{2+} \mathrm{T}_{465}$ SVLGVKDETAGVTTLK $_{481}$ & A, B & 317.1 \\
\hline $\begin{array}{l}693.4[\mathrm{M}+3 \mathrm{H}]^{3+} ; 1039.6 \\
{[\mathrm{M}+2 \mathrm{H}]^{2+}}\end{array}$ & 2078.2 & $240.0,280.1,324.1,342.1$ & $860.1[\mathrm{M}+2 \mathrm{H}]^{2+} \mathrm{T}_{465}$ SVLGVKDETAGVTTLK $_{481}$ & A, B & 360.1 \\
\hline $\begin{array}{l}698.0[\mathrm{M}+3 \mathrm{H}]^{3+} ; 1046.6 \\
{[\mathrm{M}+2 \mathrm{H}]^{2+}}\end{array}$ & 2092.2 & 374.1 & $860.1[\mathrm{M}+2 \mathrm{H}]^{2+} \mathrm{T}_{465}$ SVLGVKDETAGVTTLK $_{481}$ & A, B & 374.1 \\
\hline $\begin{array}{l}532.2[\mathrm{M}+3 \mathrm{H}]^{3+} ; 797.9 \\
{[\mathrm{M}+2 \mathrm{H}]^{2+}}\end{array}$ & 1594.8 & $275.0,299.1,316.1,334.1$ & $1279.7[\mathrm{M}+\mathrm{H}]^{+} \mathrm{I}_{180}$ TSGGEVQFTLK $_{191}$ & $A, B$ & 316.1 \\
\hline $\begin{array}{l}532.6[\mathrm{M}+3 \mathrm{H}]^{3+} ; 798.4 \\
{[\mathrm{M}+2 \mathrm{H}]^{2+}}\end{array}$ & 1595.8 & $281.0,299.0,317.1$ & $1279.7[\mathrm{M}+\mathrm{H}]^{+} \mathrm{I}_{180}$ TSGGEVQFTLK $_{191}$ & A, B & 317.1 \\
\hline $532.2[\mathrm{M}+3 \mathrm{H}]^{3+}$ & 1594.6 & $275.0,299.1,316.1,334.1$ & $1279.7[\mathrm{M}+\mathrm{H}]^{+} \mathrm{I}_{180}$ TSGGEVQFTLK $_{191}$ & A, B & \\
\hline $\begin{array}{l}753.8[\mathrm{M}+3 \mathrm{H}]^{3+} ; 1130.1 \\
{[\mathrm{M}+2 \mathrm{H}]^{2+}}\end{array}$ & 2259.2 & $275.1,316.1,334.1$ & $1944.0[\mathrm{M}+\mathrm{H}]^{+} \mathrm{V}_{204} \mathrm{VISTSVGTGLGALADEINK}_{223}$ & A & 316.1 \\
\hline $\begin{array}{l}754.1[\mathrm{M}+3 \mathrm{H}]^{3+} ; 1130.6 \\
{[\mathrm{M}+2 \mathrm{H}]^{2+}}\end{array}$ & 2260.2 & $281.0,299.1,317.1$ & $\begin{array}{c}972.6[\mathrm{M}+2 \mathrm{H}]^{2+} ; 1944.0[\mathrm{M}+\mathrm{H}]^{+} \\
\mathrm{V}_{204} \text { VISTSVGTGLGALADEINK }_{223}\end{array}$ & A & 317.1 \\
\hline $\begin{array}{l}950.5[\mathrm{M}+4 \mathrm{H}]^{4+} ; 1266.9 \\
{[\mathrm{M}+3 \mathrm{H}]^{3+}}\end{array}$ & 3798.7 & $275.0,299.0,316.1$ & $\begin{array}{l}\text { Loss of one glycan: } 1161.8[\mathrm{M}+3 \mathrm{H}]^{3+} \\
\mathrm{N}_{335} \text { DGKDILVSGTGLTAAGFGANSFISQASISLR }{ }_{366}\end{array}$ & A, B & $\begin{array}{l}\text { 316.1, two gly- } \\
\text { cans }\end{array}$ \\
\hline $950.8[\mathrm{M}+4 \mathrm{H}]^{4+}$ & 3802.2 & $275.0,281.0,299.0,316.1,317.1$ & $\begin{array}{l}\text { Loss of one glycan: } 1161.8[\mathrm{M}+3 \mathrm{H}]^{3+} \\
\mathrm{N}_{335} \text { DGKDILVSGTGLTAAGFGANSFISQASISLR } \\
366\end{array}$ & A, B & $316.1,317.1$ \\
\hline $951.0[\mathrm{M}+4 \mathrm{H}]^{4+}$ & 3803.0 & $281.0,299.1,317.1$ & $\begin{array}{l}\text { Loss of one glycan: } 1161.8[\mathrm{M}+3 \mathrm{H}]^{3+} \\
\mathrm{N}_{335} \text { DGKDILVSGTGLTAAGFGANSFISQASISLR } \\
366\end{array}$ & A, B & $\begin{array}{l}\text { 317.1, two gly- } \\
\text { cans }\end{array}$ \\
\hline $\begin{array}{l}846.9[\mathrm{M}+4 \mathrm{H}]^{4+} ; 1128.9 \\
{[\mathrm{M}+3 \mathrm{H}]^{3+}}\end{array}$ & 3384.7 & $275.0,316.1$ & $\mathrm{D}_{339}$ ILVSGTGLTAAGFGANSFISQASISLR $_{366}$ & A, B & $\begin{array}{l}\text { 316.1, two gly- } \\
\text { cans }\end{array}$ \\
\hline $\begin{array}{l}847.2[\mathrm{M}+4 \mathrm{H}]^{4+} ; 1129.2 \\
{[\mathrm{M}+3 \mathrm{H}]^{3+}}\end{array}$ & 3385.8 & $281.0,299.1,317.1$ & $\mathrm{D}_{339}$ ILVSGTGLTAAGFGANSFISQASISLR $_{366}$ & A, B & $\begin{array}{l}\text { 317.1, two gly- } \\
\text { cans }\end{array}$ \\
\hline $\begin{array}{l}748.1[\mathrm{M}+3 \mathrm{H}]^{3+} ; 561.3 \\
{[\mathrm{M}+4 \mathrm{H}]^{4+}}\end{array}$ & 2242.3 & $275.0,288.1,299.0,316.1$ & $963.8[\mathrm{M}+2 \mathrm{H}]^{2+} \mathrm{F}_{174}$ ETGGRITSGGEVQFTLK $_{191}$ & A, B & 316.1 \\
\hline $748.4[\mathrm{M}+3 \mathrm{H}]^{3+}$ & 2243.2 & $\mathrm{ND}^{*}$ & $\mathrm{~F}_{174}$ ETGGRITSGGEVQFTLK $_{191}$ & A, B & 317.1 \\
\hline $896.8[\mathrm{M}+3 \mathrm{H}]^{3+}$ & 2688.4 & $281.1,299.0,317.1$ & $1186.6[\mathrm{M}+2 \mathrm{H}]^{2+} \mathrm{V}_{204} \mathrm{VISTSVGTGLGALADEINK} \mathrm{NADK}_{227}$ & A & 317.1 \\
\hline $758.8[\mathrm{M}+3 \mathrm{H}]^{3+}$ & 2274.4 & $281.1,299.0,317.1$ & $979.5[\mathrm{M}+2 \mathrm{H}]^{2+} \mathrm{V}_{204}$ VISTSVGTGLGALAEEINK $_{223}$ & B & 317.1 \\
\hline
\end{tabular}

${ }^{*}$ ND, Not determined 
identity of the peptide was confirmed by performing an addition ion selection/fragmentation cycle with the fragment at $m / z 860$ ( $\mathrm{MS}^{3}$ experiment), which provided a series of $\mathrm{Y}$ ions with peptide sequence information (Fig. 5f). Another, minor glycoform, which was likewise exclusively observed for the 108 parent strain, resulted in an oxonium ion at $\mathrm{m} / z 374$ upon MS-MS, next to the peptide signal $(\mathrm{m} /$ $z$ 860).

\section{High-resolution MS of the novel flagellin glycoforms}

To characterize the novel flagellar monosaccharides in more detail the tryptic digest of the flagellin of strain 108WT was fractionated by reverse-phase HPLC and analysed by MALDI-FT-ICR-MS. The masses of the various glycoforms of $\mathrm{T}_{465}-\mathrm{K}_{481}$ were determined with sub-p.p.m. mass accuracy (Fig. 6a, Table 3). The signals for the glycopeptides with Pse5Am7Ac and Pse5Ac7Ac were overlapping (Fig. 6b): two peaks at $\mathrm{m} / z 2035.0747$ and $\mathrm{m} / \mathrm{z}$ 2035.1094 could be partially resolved, representing the first isotope peak of Pse5Am7Ac and the second isotope peak of Pse5Ac7Ac, respectively (Fig. 6c). The non-glycosylated form of peptide $\mathrm{T}_{465}-\mathrm{K}_{481}$ was detected at $\mathrm{m} / z 1718.9525$. The two novel glycoforms were detected at $m / z 2078.0868$ (Fig. 6d) and $m / z 2092.1032$ (Fig. 6e). From these data the masses of the corresponding glycan moieties (oxonium ions) were calculated $(\mathrm{m} / \mathrm{z} 360.1406$ and $\mathrm{m} / \mathrm{z}$ 374.1570; Table 3) and used to search for possible molecular compositions.

As the modification was expected to be a derivative of Pse5Ac/Am7Ac, only molecular compositions within the range $\mathrm{C}_{13-20} \mathrm{H}_{18-30} \mathrm{~N}_{1--8} \mathrm{O}_{5-10}$ were taken into account. Within the expected mass accuracy range of $\pm 2 \mathrm{mDa}$ the only matching molecular composition for the glycan of $\mathrm{m} / z$

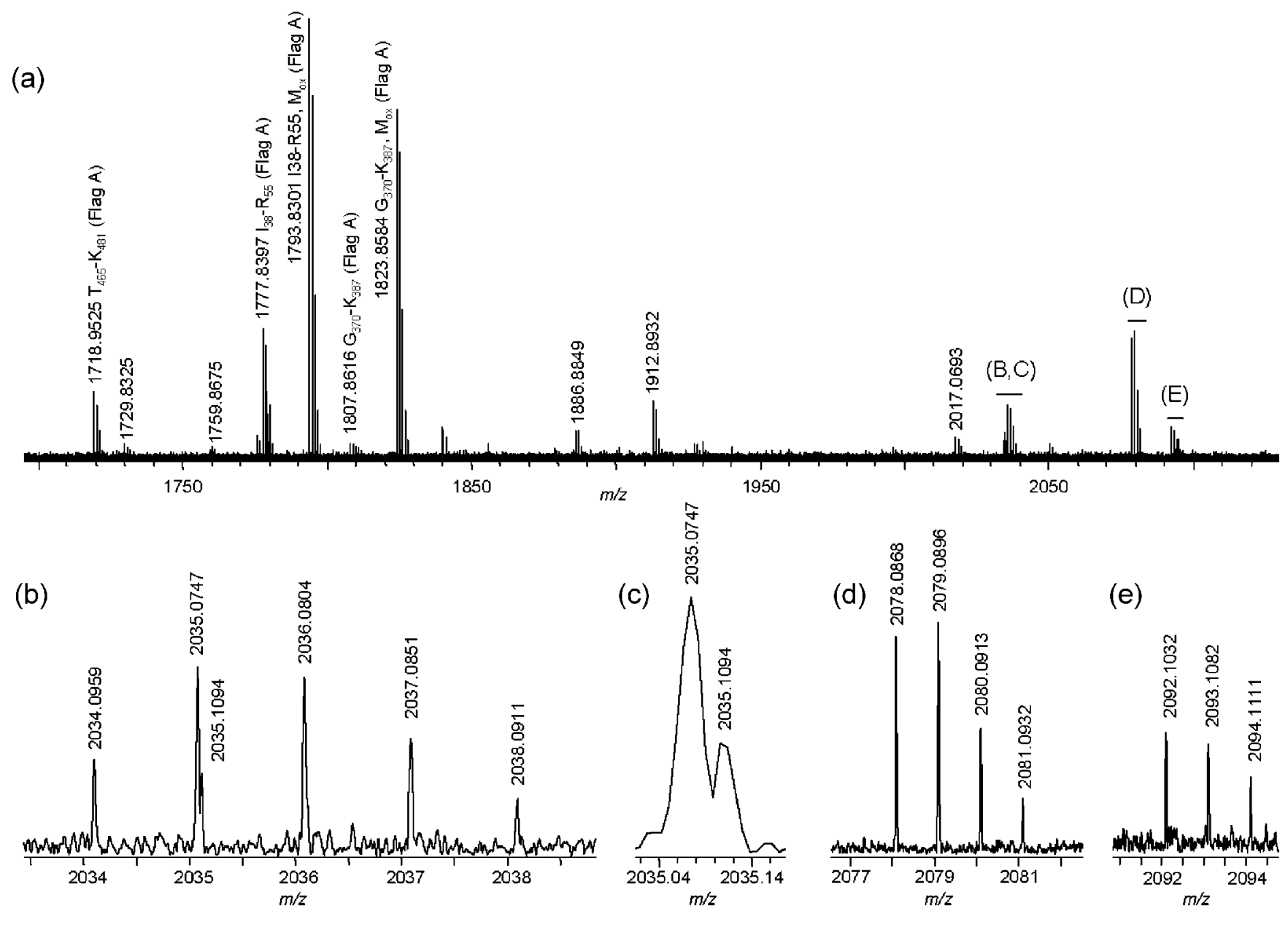

Fig. 6. MALDI-FT-ICR-MS analysis of the glycoforms of the tryptic peptide $T_{465}-K_{481}$ of FlaA. The tryptic digest of bacterial flagellins was fractionated by reverse-phase HPLC. The fraction containing the glycoforms of the tryptic peptide $\mathrm{T}_{465}-\mathrm{K}_{481}$ was analysed by MALDI-FT-ICR-MS (a). In addition to the glycoforms with Pse5Am7Ac ( $m / z$ 2034.0959) and Pse5Ac7Ac (2035.0747) (b, c), two additional glycoforms were determined representing novel pseudaminic acid derivatives $(\mathrm{m} / \mathrm{z}$ 2078.0868 and $\mathrm{m} / \mathrm{z} 2092.1032)(\mathrm{d}, \mathrm{e}$ ). The accurate masses were used to deduce the molecular composition of the attached glycan moieties (see Table 3). 
Table 3. Analysis of the glycoforms of the differentially glycosylated peptide by MALDI-FT-ICR-MS

\begin{tabular}{|c|c|c|c|c|}
\hline $\begin{array}{l}\text { Registered masses } \\
{[\mathrm{M}+\mathrm{H}]^{+}}\end{array}$ & $\begin{array}{c}\text { Deduced mass of } \\
\text { modification } \\
{[\mathrm{M}+\mathrm{H}]^{+}}\end{array}$ & Compound & $\begin{array}{l}\text { Theoretical mass } \\
\qquad[\mathbf{M}+\mathbf{H}]^{+}\end{array}$ & Mass accuracy \\
\hline 1718.9525 & - & $\mathrm{T}_{465}$ SVLGVKDETAGVTTLK $_{481}$ (Flag A) & 1718.9535 & $0.0010 \mathrm{mDa}(0.6$ p.p.m.) \\
\hline 2017.0693 & 299.1238 & $\mathrm{~T}_{465}-\mathrm{K}_{481}$ with $\mathrm{C}_{13} \mathrm{H}_{18} \mathrm{O}_{6} \mathrm{~N}_{2}$ & 2017.0700 & $0.0007 \mathrm{mDa}$ (0.3 p.p.m.) \\
\hline 2034.0959 & 316.1497 & $\mathrm{~T}_{465}-\mathrm{K}_{481}$ with $\mathrm{C}_{13} \mathrm{H}_{21} \mathrm{O}_{6} \mathrm{~N}_{3}$ (Pse5Am7Ac) & 2034.0965 & $0.0007 \mathrm{mDa}(0.3$ p.p.m. $)$ \\
\hline $\begin{array}{l}\text { 2035.0747; 2038.0911 } \\
\text { (fourth isotope peak) }\end{array}$ & 317.1348 & $\mathrm{~T}_{465}-\mathrm{K}_{481}$ with $\mathrm{C}_{13} \mathrm{H}_{20} \mathrm{O}_{7} \mathrm{~N}_{2}$ (Pse5Ac7Ac) & $\begin{array}{l}2035.0805 ; 2038.0906 \\
\text { (fourth isotope peak) }\end{array}$ & $0.0005 \mathrm{mDa}(0.2 \text { p.p.m. })^{\star}$ \\
\hline 2078.0868 & 360.1406 & $\mathrm{~T}_{465}-\mathrm{K}_{481}$ with $\mathrm{C}_{14} \mathrm{H}_{21} \mathrm{O}_{8} \mathrm{~N}_{3}$ & 2078.0863 & $0.0005 \mathrm{mDa}(0.2$ p.p.m. $)$ \\
\hline 2092.1032 & 374.1570 & $\mathrm{~T}_{465}-\mathrm{K}_{481}$ with $\mathrm{C}_{15} \mathrm{H}_{23} \mathrm{O}_{8} \mathrm{~N}_{3}$ & 2092.1020 & $0.0012 \mathrm{mDa}$ (0.6 p.p.m.) \\
\hline
\end{tabular}

${ }^{\star}$ Calculated for the fourth isotope peak.

360.1406 was $\mathrm{C}_{14} \mathrm{H}_{21} \mathrm{O}_{8} \mathrm{~N}_{3}$. The compositional difference between this glycan $\left(\mathrm{C}_{14} \mathrm{H}_{21} \mathrm{O}_{8} \mathrm{~N}_{3}\right)$ and Pse5Am7Ac $\left(\mathrm{C}_{13} \mathrm{H}_{21} \mathrm{O}_{6} \mathrm{~N}_{3}\right)$ is $\mathrm{CO}_{2}$, indicating that the $360 \mathrm{kDa}$ glycoform may be Pse5Am7Ac substituted with additional carboxylic acid group. This modification fits with the lower average pI of $108 \mathrm{WT}$ flagellins compared with $108 \Delta$ maf4 flagellins in 2D gels (Fig. 4). For the $374 \mathrm{Da}$ glycan (calculated oxonium ion of $\mathrm{m} / z$ 374.1570), two possible matches were found: $\mathrm{C}_{15} \mathrm{H}_{23} \mathrm{O}_{8} \mathrm{~N}_{3}$ with a calculated mass of $\mathrm{m} / \mathrm{z} 374.1558(\Delta \mathrm{m}=1.2 \mathrm{mDa})$, and $\mathrm{C}_{18} \mathrm{H}_{22} \mathrm{O}_{5} \mathrm{~N}_{4}$ with a calculated mass of $\mathrm{m} / \mathrm{z} 374.1585$ $(\Delta \mathrm{m}=1.5 \mathrm{mDa})$. The first option $\left(\mathrm{C}_{15} \mathrm{H}_{23} \mathrm{O}_{8} \mathrm{~N}_{3}\right)$ seems the more probable one, as this would mean a compositional difference of $\mathrm{CH}_{2}$ compared with the 360 Da glycan. Overall, the results indicate that Maf4 alters the glycosylation of the flagellin in the peptide region $\mathrm{T}_{465}-\mathrm{K}_{481}$ by enabling the addition (or formation) of Pse5Am7Ac substituted with an additional carboxyl group, resulting in a more acidic glycopeptide.

\section{Maf4 influences $C$. jejuni autoagglutination kinetics}

What are the functional consequences of the presence of a functional Maf4? This question was addressed first by testing the in vitro behaviour of a highly invasive derivative of strain 108WT (designated 108P4) (van Alphen et al., 2008). Sequencing of the poly-G region of maf4 of 108P4 confirmed that no slipped-strand mispairing had occurred during the selection of this strain and that the gene was in the 'on' state (data not shown). To analyse the role of maf4 in strain 108P4 the gene was inactivated as described for 108WT. 2D-PAGE analysis of the flagellins of strains 108P4 and $108 \mathrm{P} 4 \Delta$ maf4 demonstrated a similar shift in $\mathrm{pI}$ to that observed for strain 108WT and its maf4-negative derivative (data not shown), suggesting that the observed effects in both mutants are caused by inactivation of the maf4 gene rather than by changes in other phase-variable genes. Infection assays with $108 \mathrm{P} 4 \Delta$ maf4 revealed unaltered (high) subvasion behaviour in Chang epithelial cells compared to 108WT (Fig. 7a). Gentamicin protection assays on infected cells using INT-407 cells indicated a slight (but consistent) increase in the number of recovered bacteria for the maf4-negative derivatives of both the highly invasive strain $108 \mathrm{P} 4$ and the low invasive strain 108WT (Fig. 7b).

We also investigated the effect of Maf4 on the autoagglutination of C. jejuni, as this trait has been associated with changes in flagellar glycosylation (Guerry et al., 2006). As shown in Fig. 7(c), incubation ( $2 \mathrm{~h}$ ) of a suspension of strain 108WT of OD 0.5 resulted in strong agglutination with the formation of a clear bacterial pellet at the bottom of the tube. In contrast, strain $108 \Delta$ maf4 was still largely in suspension at this time point (Fig. 7c). Measurement of the ODs of the bacterial suspension at different time points confirmed the altered agglutination behaviour of the maf4 mutant (Fig. 7d). At $5 \mathrm{~h}$ of incubation both strain 108WT and $108 \Delta$ maf4 had agglutinated (Fig. $7 \mathrm{~d}$ ), in contrast to the strain lacking flagellin. These results suggest that the Maf4induced post-translational modification influences the kinetics of the flagellin-mediated bacterial agglutination, and thus that the maf4 gene in the 'on' state may alter the population behaviour of $C$. jejuni.

\section{DISCUSSION}

In the present study we identified a functional, potentially phase-variable gene (maf4) involved in post-translational modification of the flagellin of the bacterial pathogen $C$. jejuni. Sequencing of maf4 from strain 108WT indicated that it contained a homopolymeric stretch of nine $G$ residues, resulting in an ORF encoding full-length protein in contrast to the homologous maf1 of strain 11168 . Evidence that Maf4 is involved in flagellin glycosylation includes the altered migration of flagellin isoforms in 2D gels after inactivation of maf4, and MS analysis of flagellin tryptic glycopeptides. Functional studies indicate that Maf4 functionality influences flagella-mediated bacterial autoagglutination. This suggests that, in the event of phase variation, variable maf4 expression alters the behaviour of C. jejuni, which may add to the virulence of the pathogen. 


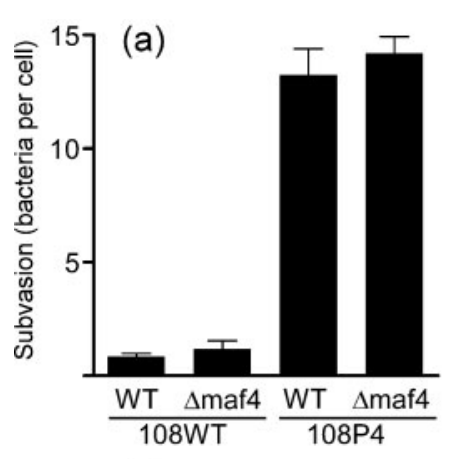

(c)

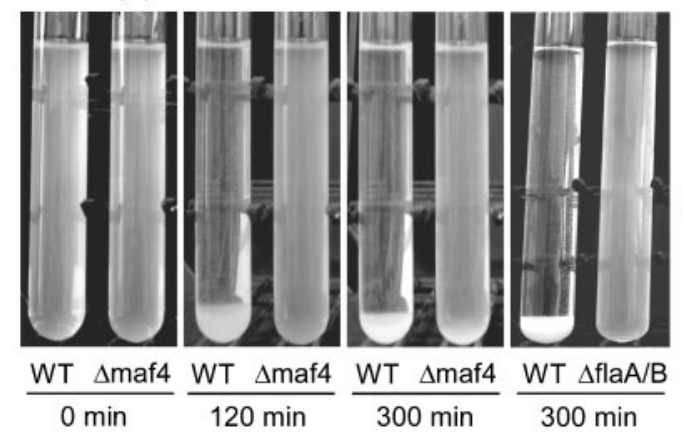

(b)

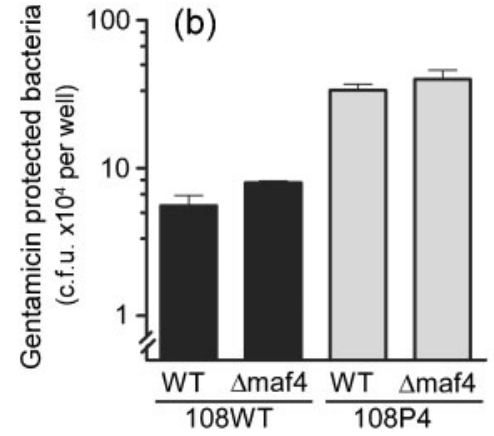

(d)

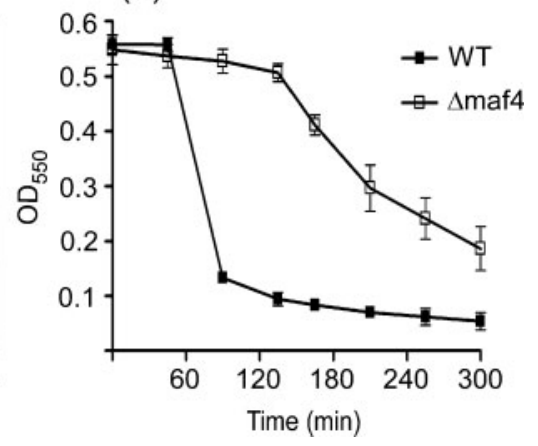

Fig. 7. Infection and autoagglutination assays. $(a, b)$ Infection assays of epithelial cells. Subvasion of Chang epithelial cells (a) and invasion of INT-407 epithelial cells (b) of strain 108WT, the highly subvasive/invasive strain 108P4, and their corresponding maf4 mutants ( $\Delta$ maf4). Data represent the mean \pm SEM of three experiments. (c, d) Autoagglutination assays. Suspensions of strain 108WT and 108 $\Delta$ maf4 were incubated for up to $5 \mathrm{~h}$ at room temperature. (c) Autoagglutination at 0,2 and $5 \mathrm{~h}$ of incubation is depicted to illustrate the difference in kinetics of pellet formation between the wild-type and the mutant strain. The non-flagellated RpoN mutant served as a control for flagella-dependent autoagglutination. (d) Kinetics of the autoagglutination as measured by the drop in $\mathrm{OD}_{550}$ over a $5 \mathrm{~h}$ period. Values represent the mean \pm SEM of three separate experiments.

Comparative genome analysis indicated that C. jejuni carries up to seven different maf genes that are all part of the C. jejuni flagellar glycosylation locus. The variable number of maf genes in different $C$. jejuni strains suggests that the maf gene repertoire is highly diverse, although analysis based on amino acid similarity allows clustering into distinct groups (Fig. 2). In most cases, the different types of maf genes are located at the same position in the flagellar glycosylation locus. Comparison of related maf genes from different strains, such as maf4 from strains 108 and 11168 , suggests that they are relatively conserved except in distinct regions. This seemingly modular architecture resembles that of certain families of enzymes, such as glycosyltransferases (Kapitonov \& Yu, 1999). In these cases, the variable domains contribute to the substrate specificity of the enzymes.

A search for maf genes carrying homopolymeric nucleotide tracts indicated that some, but not all, strains contain one or two potentially phase-variable genes. Interestingly, the homopolymeric stretch of nucleotides was in all except one strain located in the mafl and/or maf4 gene, suggesting that these genes are particularly attractive loci for the bacterium to undergo phase variation. The finding that maf1/4 genes with both intact and truncated ORFs exist in nature suggests that slipped-strand mispairing occurs and is not harmful to the bacterium. Indeed, phase variation of maf1 (which identical to maf4) has been demonstrated to occur for strain 11168 (Karlyshev et al., 2002). Why maf1/4 is phase variable in contrast to, e.g. maf5, is unclear, but may be related to the apparently essential function of maf5 in flagella assembly (Karlyshev et al., 2002).

The unchanged swarming behaviour of our maf4 mutant in semisolid agar (Fig. 4a) indicates that the gene is not essential for motility of $C$. jejuni. This is surprising, as maf genes have been implicated as determinants of bacterial motility in strain 11168 (Karlyshev et al., 2002), although inactivation of maf2 and maf3 does not result in loss of motility in strain 81-176 (Guerry et al., 2006; McNally et al., 2006). The finding that insertional inactivation of maf4 still allowed flagella assembly enabled us to investigate the glycosylation status of the flagellin in the mutant strain. Comparison of the flagellins of $108 \mathrm{WT}$ and $108 \Delta$ maf4 by 2D-PAGE analysis demonstrated multiple flagellin spots with different $\mathrm{pI}$ values, consistent with the existence of multiple glycoforms in both strains (Thibault et al., 2001).

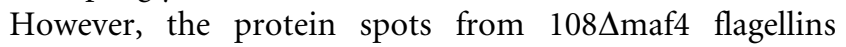


migrated on average toward the less acidic region of the IEF gel. This observation fits with MS results regarding the apparent decoration of the flagellin of strain 108WT, but not that of $108 \Delta$ maf4, with Pse5Am7Ac possessing an additional $\mathrm{CO}_{2}$ or $\mathrm{C}_{2} \mathrm{H}_{2} \mathrm{O}_{2}$ moiety. The more acidic glycoforms were found for the peptide region $\mathrm{T}_{465}-\mathrm{K}_{481}$, which is shared between FlaA and FlaB. As only part of the bacterial $O$-glycosylation sites was monitored in our LCMS approach, additional sites carrying these glycans may exist, which likewise may contribute to the differences in $\mathrm{pI}$ of the bacterial flagellins of the two strains. Considering the nature of the modification of Pse5Am7Ac in the Maf4positive strain, it is possible that Maf4 facilitates additional carboxylation of nucleotide-activated Pse5Am7Ac. Alternatively, the protein may have no role in the biosynthesis but may specifically transfer the novel Pse5Am7Ac derivative(s) to the flagellin protein. Also, insertional inactivation of the maf2 ( $p s e D)$ gene does not interfere with the biosynthesis of pseudaminic acid precursors (McNally et al., 2006) but results in a specific lack of Pse5Am7Ac but not Pse5Ac7Ac glycans on flagellin (Guerry et al., 2006), consistent with substrate-specific transfer of the glycans.

The exact function of flagellar glycosylation in C. jejuni biology is not well understood. Our results indicate a clear difference in flagella-mediated autoagglutination between the flagellated strain 108WT and its maf4-defective derivative (Fig. 7). Autoagglutination of $C$. jejuni has been reported to influence flagella typing methods based on lectin interactions (Wong et al., 1985), co-agglutination (Wong et al., 1985) and serospecificity (Lior et al., 1981). The self-aggregation is associated with the presence of flagella and with cell surface hydrophobicity (Misawa \& Blaser, 2000). The role of flagella has been confirmed in a random transposon mutagenesis screen on C. jejuni 480 that showed autoagglutination to be influenced by genes in the flagellar glycosylation locus (Golden \& Acheson, 2002). Because of the absence of autoagglutination after a loss of flagellar Pse5Am7Ac (but not Pse5Ac7Ac) residues (Guerry et al., 2006), it has been proposed that interactions between both glycan forms across flagellar filaments are crucial in the aggregative interaction. However, it has been difficult to study this interaction, as bacteria unable to decorate their flagellins fail to build a functional flagellum (Karlyshev et al., 2002). Our results indicate that the addition of $\mathrm{CO}_{2}(\mathrm{~m} / \mathrm{z} 360.1)$ or $\mathrm{C}_{2} \mathrm{H}_{2} \mathrm{O}_{2}(\mathrm{~m} / \mathrm{z} 374.1)$ groups to Pse5Ac7Ac strongly accelerates bacterial autoagglutination, suggesting a perhaps even more intense interaction of the more acidic Pse5Ac7Ac flagellin with other glycoforms. In other studies, a correlation has been found between autoagglutination and bacterial invasion of INT-407 cells (Guerry et al., 2006). In our hands, similar numbers of gentamicin-protected bacteria were recovered from INT407 cells for parental strains 108WT and 108P4 and their maf4-negative derivatives. Furthermore, no differences in subvasive behaviour (van Alphen et al., 2008) could be detected between the parental and Maf4-mutant strains.
Here, we demonstrated for the first time, to our knowledge, that the presence of a functional maf4 gene of $C$. jejuni results in a novel glycan modification of the flagellin and enhanced bacterial autoagglutination compared with a maf4-negative strain. On the basis of these results it can be expected that variable functionality of Maf4, as occurs in the event of phase variation due to the changes in the poly- $G$ tract in the maf4 gene, influences the glycosylation status of flagellin and alters the population behaviour of C. jejuni.

\section{ACKNOWLEDGEMENTS}

The authors thank Carolien A. M. Koeleman and Irina Dragan for expert technical assistance.

\section{REFERENCES}

Alm, R. A., Guerry, P., Power, M. E., Lior, H. \& Trust, T. J. (1991). Analysis of the role of flagella in the heat-labile Lior serotyping scheme of thermophilic Campylobacters by mutant allele exchange. J Clin Microbiol 29, 2438-2445.

Caldwell, M. B., Guerry, P., Lee, E. C., Burans, J. P. \& Walker, R. I. (1985). Reversible expression of flagella in Campylobacter jejuni. Infect Immun 50, 941-943.

Doig, P., Kinsella, N., Guerry, P. \& Trust, T. J. (1996). Characterization of a post-translational modification of Campylobacter flagellin: identification of a sero-specific glycosyl moiety. Mol Microbiol 19, 379-387.

Endtz, H. P., Giesendorf, B. A., van Belkum, A., Lauwers, S. J., Jansen, W. H. \& Quint, W. G. (1993). PCR-mediated DNA typing of Campylobacter jejuni isolated from patients with recurrent infections. Res Microbiol 144, 703-708.

Golden, N. J. \& Acheson, D. W. (2002). Identification of motility and autoagglutination Campylobacter jejuni mutants by random transposon mutagenesis. Infect Immun 70, 1761-1771.

Guerry, P., Ewing, C. P., Schirm, M., Lorenzo, M., Kelly, J., Pattarini, D., Majam, G., Thibault, P. \& Logan, S. (2006). Changes in flagellin glycosylation affect Campylobacter autoagglutination and virulence. Mol Microbiol 60, 299-311.

Kapitonov, D. \& Yu, R. K. (1999). Conserved domains of glycosyltransferases. Glycobiology 9, 961-978.

Karlyshev, A. V., Linton, D., Gregson, N. A. \& Wren, B. W. (2002). A novel paralogous gene family involved in phase-variable flagellamediated motility in Campylobacter jejuni. Microbiology 148, 473-480.

Kumar, S., Tamura, K. \& Nei, M. (2004). MEGA3: integrated software for Molecular Evolutionary Genetics Analysis and sequence alignment. Brief Bioinform 5, 150-163.

Lior, H., Woodward, D. L., Edgar, J. A. \& LaRoche, L. J. (1981). Serotyping by slide agglutination of Campylobacter jejuni and epidemiology. Lancet 2, 1103-1104.

Logan, S. M. (2006). Flagellar glycosylation - a new component of the motility repertoire? Microbiology 152, 1249-1262.

Logan, S. M., Trust, T. J. \& Guerry, P. (1989). Evidence for posttranslational modification and gene duplication of Campylobacter flagellin. J Bacteriol 171, 3031-3038.

Logan, S. M., Kelly, J. F., Thibault, P., Ewing, C. P. \& Guerry, P. (2002). Structural heterogeneity of carbohydrate modifications affects serospecificity of Campylobacter flagellins. Mol Microbiol 46, 587-597. 
McNally, D. J., Hui, J. P., Aubry, A. J., Mui, K. K., Guerry, P., Brisson, J. R., Logan, S. M. \& Soo, E. C. (2006). Functional characterization of the flagellar glycosylation locus in Campylobacter jejuni 81-176 using a focused metabolomics approach. J Biol Chem 281, 1848918498 .

McNally, D. J., Aubrey, A. J., Hui, J. P., Khieu, N. H., Whitfield, D., Ewing, C. P., Guerry, P., Brisson, J. R., Logan, S. M. \& Soo, E. C. (2007). Targeted metabolomics analysis of Campylobacter coli VC167 reveals legionaminic acid derivatives as novel flagellar glycans. J Biol Chem 282, 14463-14475.

Misawa, N. \& Blaser, M. J. (2000). Detection and characterization of autoagglutination activity by Campylobacter jejuni. Infect Immun $\mathbf{6 8}$, 6168-6175.

Samatey, F. A., Imada, K., Nagashima, S., Vonderviszt, F., Kumasaka, T., Yamamoto, M. \& Namba, K. (2001). Structure of the bacterial flagellar protofilament and implications for a switch for supercoiling. Nature 410, 331-337.

Schirm, M., Schoenhofen, I. C., Logan, S. M., Waldron, K. C. \& Thibault, P. (2005). Identification of unusual bacterial glycosylation by tandem mass spectrometry analyses of intact proteins. Anal Chem 77, 7774-7782.

Shevchenko, A., Wilm, M., Vorm, O. \& Mann, M. (1996). Mass spectrometric sequencing of proteins from silver-stained polyacrylamide gels. Anal Chem 68, 850-858.
Steen, H., Kuster, B., Fernandez, M., Pandey, A. \& Mann, M. (2002). Tyrosine phosphorylation mapping of the epidermal growth factor receptor signaling pathway. J Biol Chem 277, 1031-1039.

Thibault, P., Logan, S. M., Kelly, J. F., Brisson, J. R., Ewing, C. P., Trust, T. J. \& Guerry, P. (2001). Identification of the carbohydrate moieties and glycosylation motifs in Campylobacter jejuni flagellin. J Biol Chem 276, 34862-34870.

van Alphen, L. B., Bleumink-Pluym, N. M. C., Rochat, K. D., Van Balkom, B. W. M., Wösten, M. M. S. M. \& van Putten, J. P. M. (2008). Active migration into the subcellular space precedes Campylobacter jejuni invasion of epithelial cells. Cell Microbiol 10, 53-66.

van Putten, J. P. M., Weel, J. F. \& Grassme, H. U. (1994). Measurements of invasion by antibody labeling and electron microscopy. Methods Enzymol 236, 420-437.

van Vliet, A. H., Wooldridge, K. G. \& Ketley, J. M. (1998). Ironresponsive gene regulation in a Campylobacter jejuni fur mutant. J Bacteriol 180, 5291-5298.

Wong, K. H., Skelton, S. K., Patton, C. M., Feeley, J. C. \& Morris, G. (1985). Typing of heat-stable and heat-labile antigens of Campylobacter jejuni and Campylobacter coli by coagglutination. J Clin Microbiol 21, 702-707.

Wösten, M. M. S. M. (1997). Initiation of transcription and gene organization in Campylobacter jejuni. PhD thesis, Utrecht University.

Edited by: P. H. Everest 